\title{
AN SRY-POSITIVE 46,XX MALE
}

\author{
Kaur A ${ }^{1, *}$, Sachdeva K ${ }^{1}$, Mahajan $\mathrm{S}^{1}$, Virk SPS ${ }^{2}$, Singh JR ${ }^{1}$
}

*Corresponding Author: Dr. Anupam Kaur, Centre for Genetic Disorders, Guru Nanak Dev University, G.T. Road, Amritsar, 143005 Punjab, India; Tel.: +91-183-2258802 to 2258809, Ext 3446; Fax: +91-183-2258863; E-mail: anupamkaur@yahoo.com

\begin{abstract}
The 46,XX karyotype in a male is a rare sex chromosomal disorder. It mostly results from unequal crossovers between the $\mathrm{X}$ and $\mathrm{Y}$ chromosomes during meiosis. We here report a 32-year-old infertile male in whom seminal analysis showed azoospermia. Chromosomal analysis revealed a 46,XX karyotype and fluorescent in situ hybridization (FISH) showed the presence of the SRY gene. This report highlights the value of karyotyping and FISH analysis in cases of infertility.
\end{abstract}

Key Words: Azoospermia; XX male; Infertile

\section{INTRODUCTION}

In the XX male syndrome, an affected individual may show normal male physical features but have a female chromosomal constitution. The syndrome occurs in approximately $1 / 20,000$ to $1 / 25,000$ individuals. Two types of XX male syndrome can occur, with or without a detectable SRY gene (region for testes determination on the $\mathrm{Y}$ chromosome), respectively. The XX males carry $35 \mathrm{~kb}$ of the Y-specific DNA on the short arm of their $\mathrm{X}$ chromosome [1]. Testes determination would be initiated in those individuals who inherit the paternal X chromosome with an SRY gene translocated from the Y chromosome [2]. The 46,XX males have testes, male habitus, azoospermia and absence of a

\footnotetext{
${ }^{1}$ Centre for Genetic Disorders, Guru Nanak Dev University, Amritsar, Punjab, India

2 SPS Virk, Centre for Human Reproduction, Jalandhar, Punjab, India
}

uterus or ovaries, thus are distinct from 46,XX true hermaphrodites who have both testicular and ovarian development $[3,4]$. We here describe a male with a 46,XX chromosomal constitution, normal male phenotype, infertility and azoospermia. The presence of the SRY gene was confirmed with fluorescent in situ hybridization (FISH).

\section{CLINICAL REPORT}

A 32-year-old male had been married for 8 years and attended the Centre for Human Reproduction, Jalandhar, Punjab, India. His childhood development had been normal and uneventful. There was no history of tuberculosis, mumps, injury to the testes and no family history of infertility. Informed consent was obtained before all investigations. He had normal facial but scanty pubic hair, his penile length was normal but the testes were small. The left testis was $17 \times 8 \mathrm{~mm}$, whereas the right testis was $21 \times 10 \mathrm{~mm}$ and each had a volume of 2.0 and $2.5 \mathrm{cc}$, respectively. Semen analysis showed complete absence of sperm, confirming azoospermia. He had high concentration of serum follicle-stimulating hormone (FSH), luteinizing hormone (LH), and low levels of serum testosterone. Serum FSH was $56.18 \mathrm{~m} \mathrm{IU/mL} \mathrm{(normal:} \mathrm{1.4-18.1),} \mathrm{LH}$ was $25.83 \mathrm{~m} \mathrm{IU} / \mathrm{mL}$ (normal 1.5-9.3); testosterone total was $179.14 \mathrm{ng} / \mathrm{mL}$ (normal: 241-827) and testosteronefree was $2.37 \mathrm{pg} / \mathrm{mL}$ (normal 8.80-27.0).

Cytogenetic and Molecular Analysis. Chromosomal preparations were made from phytohemagglutinin-stimulated peripheral lymphocytes using RPMI1640 medium and standard culturing technique with modifications [5]. Chromosomal banding was done 
by trypsin-Giemsa GTG banding. We examined 100 metaphases for numerical and structural abnormalities and 10 metaphases were karyotyped. All metaphases showed the 46,XX chromosomal complement. Fluorescent in situ hybridization was carried out with an LSI SRY spectrum orange probe according to the manufacturer's instructions (Vysis UK Ltd., now part of Abbott Molecular, Des Plaines, IL, USA). After hybridization, chromosomes were counterstained with DAPI and viewed by using a triple band-pass filter and Quips Smart Capture Imaging Software (Vysis UK Ltd.). Five hundred metaphase and interphase cells were scored that revealed the presence of the SRY region on cells.

\section{DISCUSSION}

The XX males were first recognized by De Le Chapelle et al. [6]. Ferguson-Smith [3] proposed that this condition resulted from an exchange of genetic material between the $\mathrm{X}$ and $\mathrm{Y}$ chromosomes during male meiosis, where the testes-determining factor gets transferred to the $\mathrm{X}$ chromosome (paternal).The inheritance of this $\mathrm{X}$ chromosomes could have caused the SRY-positive XX maleness in our patient. The FSH and LH levels were high and he had low levels of both total and free testosterone, accompanied by normal but small testes. A 46,XX boy with an SRY gene, without genital anomalies and progressive increase in FSH levels, indicating failure of germinal epithelium has been reported [7]. In five infertile XX males, the FSH levels were elevated in three and LH level raised in two cases, whereas the testosterone levels were low in three cases [8]; they showed different variants in their phenotypes, such as small penises, hypospadias, cryptorchidism, flat scrotums and in some, small testes. Similarly, in five 46,XX males (2-7 years old), low levels of serum testosterone and normal levels of FSH and LH were observed; molecular studies showed the presence of the SRY gene in three boys [9].

Since 46,XX males can be missed without kayotyping, chromosomal analysis along with molecular studies is very important in cases of infertility. Fluorescent in situ hybridization is an important technique to identify the presence of the SRY gene, even in the absence of the $\mathrm{Y}$ chromosome. Molecular studies have detected $\mathrm{Y}$ chromosome material in $75 \%$ of $\mathrm{XX}$ males. In Y-negative cases, it has been postulated that sex reversal can be due to a defect on an unidentified autosomal or X-linked sex determination gene [10].
Molecular studies of XX males would be very useful for the isolation of genes that are important for normal testicular development.

\section{ACKNOWLEDGMENTS}

This study was supported by DBT grants (BT/ $\mathrm{TF} / 09 / 21 / 90$ ) (to JRS).

\section{REFERENCES}

1. Sinclair AH, Berta P, Palmer MS, Hawkins JR, Griffiths BL, Smith MJ, Foster JW, Frischauf AM, Lovell-Badge R, Goodfellow PN. A gene from the human sex-determining region encodes a protein with homology to a conserved DNA binding motif. Nature 1990; 346(6281): 216-217.

2. McElreavey K, Cortes L. X-Y Translocation and sex differentiation. Reprod Med 2001; 19(2): 133-139.

3. Ferguson-Smith MA. X-Y Chromosomal interchange in the aetiology of the true hermaphoditism and of XX male. Lancet 1966; 2(7461): 475-476.

4. McElreavey K, Rappaport R, Vilian E, Abbas N, Richaud F, Lortat-Jacob S, Berger R, Leconiat M, Boucekkine C, Kucheria K, Temtamy S, Nuhoul-Fekete C, Brauner R, Marc Fellous. A minority of 46, XX true hermaphrodites are positive for the Y-DNA sequence including SRY. Hum Genet 1992; .90(1-2): 121-125.

5. Kaur A, Mahajan S, Singh JR. Cytogenetic investigation in mentally retarded individuals. Int $\mathrm{J}$ Hum Genet 2003; 3(1):13-16.

6. De La Chapelle A, Tippett PA, Wettestrand G, Page D. Genetic evidence of X-Y interchange in human XX male. Nature 1984; 307(5497): 170-171.

7. Rego A, Margarit E, Estivill X, Regal M, GarciaMayor RV. Development in a 46,XX boy with positive SRY gene. J Pediatr Endocrinol Metab 1996; 9(6): 623629.

8. Castineyra G, Copelli S, Levalle O. 46,XX Male: clinical, hormonal/genetic findings. Arch Androl 2002; 48(4): 251-257.

9. Li JH, Huang TH, Jiang XW, Xie QD. 46, XX Male sex reversal syndrome. Asian J Androl 2004; 6(2): 165-167.

10. Vernole P, Terrinoni A, Didona B, Laurenzi V, Rossi P, Melino G, Grimaldi P. An SRY-negative XX male with Huriez syndrome. Clin Genet 2000; 57(1): 61-66. 